\title{
Can groundwater secure drinking-water supply and supplementary irrigation in new settlements of North-West Cambodia?
}

\author{
Jean Michel Vouillamoz ${ }^{1}$ Rémi Valois ${ }^{2}$ - Sambo Lun ${ }^{2,3} \cdot$ Delphine Caron $^{1}$. \\ Ludovic Arnout ${ }^{4}$
}

Received: 7 April 2015 / Accepted: 30 September 2015 / Published online: 22 October 2015

(C) The Author(s) 2015. This article is published with open access at Springerlink.com

\begin{abstract}
Since the end of the Cambodian Civil War in 1998, the population of the Oddar Meanchey province has drastically increased despite the lack of adequate infrastructure, including basic amenities such as drinking-water supply. To improve the access to drinking water, governmental and aid agencies have focussed on drilling shallow boreholes. The use of groundwater for irrigation is also a growing concern to cope with the occasional late arrival of the rainy season or to produce food during the dry season. Since the groundwater resource in the province has not been documented, a 4-year study was undertaken (2011-2014), aiming to estimate the capability of groundwater to supply domestic needs and supplementary irrigation for rice production. Aquifer properties were estimated by combined use of hydrogeological techniques with the geophysical magnetic resonance sounding method. Groundwater storage and recharge were estimated based on new developments in the application of the geophysical method for quantifying specific yield. The median groundwater storage of the targeted sandstone aquifer is $173 \mathrm{~mm}$, the recharge is diffuse and annually ranges from 10 to $70 \mathrm{~mm}$, and the transmissivity is low to medium.
\end{abstract}

Jean Michel Vouillamoz

jean-michel.vouillamoz@ird.fr

1 IRD/UJF-Grenoble-1/CNRS/G-INP - UMR LTHE, 08BP841 Cotonou, Benin

2 French Red Cross, No. 79, St 112, S/K Toek La ak 1, Khan Tuol Kork, Phnom Penh, Cambodia

3 Department of Environment Systems, Graduate School of Frontier Sciences, The University of Tokyo, 5-1-5 Kashiwanoha, Kashiwa, Chiba 277-8563, Japan

4 French Red Cross, Setthathirath Street, Impasse Xiengnhune, Vientiane Capital, Lao PDR
Simulations of pumping indicate that the aquifer can easily supply $100 \mathrm{~L}$ of drinking water per capita daily, even considering the estimated population in 2030 . However, the shallow aquifer can generally not deliver enough water to irrigate paddy fields of several hectares during a 2-month delay in the onset of the monsoon.

Keywords Cambodia · Groundwater development . Groundwater recharge $\cdot$ Irrigation $\cdot$ Geophysics

\section{Introduction}

At the moment, about $34 \%$ of rural inhabitants of Cambodia do not have access to safe drinking water (WHO and UNICEF 2014 ) and $15-25 \%$ of the population is undernourished (WFP 2014). National averages mask inequalities: vulnerable people living in the recently developing Oddar Meanchey province cannot access safe drinking water and face periodic food shortage.

The Oddar Meanchey Province is located in North-West Cambodia (Fig. 1) where the former Khmer Rouge army maintained its last stronghold during the Cambodian Civil War. The area was entirely liberated in 1998 and the new Oddar Meanchey province was then formed in 1999. After the liberation, the population of the province increased from 69,279 in 1998 to 185,819 in 2008 (National Institute of Statistics 2009) because people returned from refugee camps and from displacement areas, but also because of the arrival of landless families coming from other provinces of Cambodia. Newcomers to Oddar Meanchey province found almost no drinking-water infrastructures: in 1998, only $2.5 \%$ of the population had access to a protected water source, while the national rate was about $30 \%$ (National Institute of Statistics 2009). For their domestic supply, people harvest rainwater 
Fig. 1 Investigated area and simplified geological map (modified from Dottin 1972) with lithology as per borehole cuttings

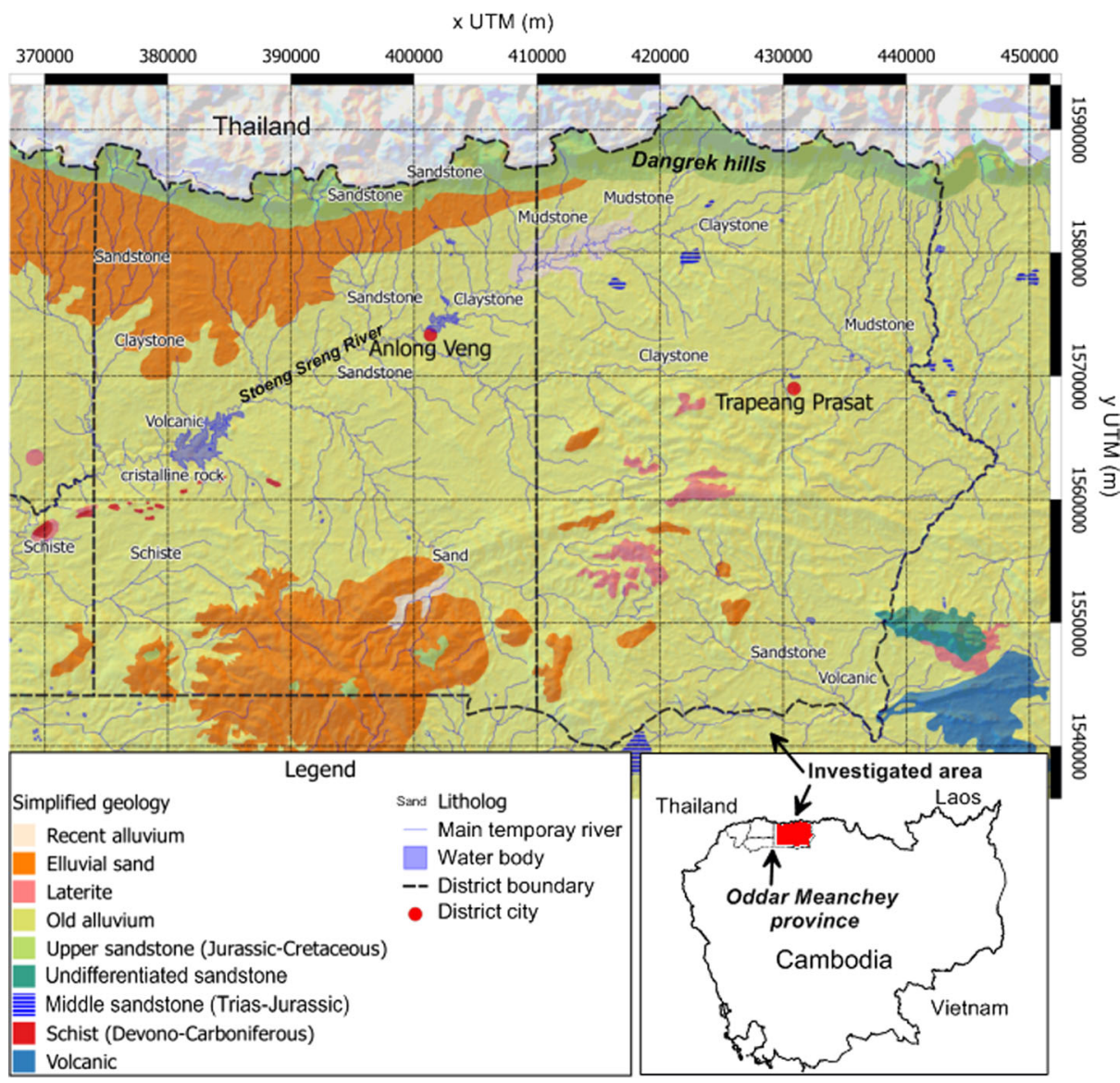

during the monsoon and then use water stored in ponds when the rain stops; however, ponds are very vulnerable to pollution and often not perennial.

Almost $90 \%$ of the families living in Oddar Meachey province are farmers and their livelihood mainly relies on a single rain-fed rice harvest per year (Nesbitt 1997). A food security study conducted in 2008 indicated that about $27 \%$ of the people living in several regions of Cambodia, including Oddar Meanchey province, were potentially food insecure during the lean season (WFP 2008). To update and specify this figure, aid organizations (the Cambodian and the French Red Cross, CRC/ FRC) carried out a survey in August 2010 among 200 villagers located in two districts of Oddar Meanchey province (Fig. 1). The assessment revealed that $80 \%$ of the people have already faced drought, i.e. a late onset of the monsoon-causing water shortage at the first growing stage of the rice production. This temporary water shortage has a direct impact on food production and availability for $87 \%$ of the families and also on income generation for $66 \%$ of them. A large majority of the interviewed people $(84 \%)$ stated that they were not prepared to face delay in the onset of the monsoon, and $86 \%$ of the people recommended improving their access to water and their storage capacity to be prepared for drought.

To supply communities with water all year round, governmental and aid agencies are supporting drilling projects. However, no quantitative assessment on groundwater resources was available in Oddar Meanchey province because of the recent history (i.e. civil war). Moreover, Oddar Meanchey is located in a geological context whose potential groundwater has rarely been investigated (e.g. Rasmussen and Bradford 1977), since most of the published works focus on the alluvial sediments of the Mekong River that are vulnerable to arsenic contamination (e.g. Berg et al. 2007). A preliminary compilation and review of information on groundwater has been completed by Landon (2011) who confirms that most of the works carried out in Cambodia concerned the alluvium units and that there is a large uncertainty in groundwater recharge estimates (e.g. JICA and MRD 2002). As mentioned by Johnston et al. (2013), the limited use of groundwater for 
irrigation in many areas of Cambodia is attributed to several reasons such as poor knowledge of the resource and its sustainability.

This report aims at improving the knowledge on groundwater potential for both the drinking-water supply and supplementary irrigation in Oddar Meanchey Province, in order to support the implementation of activities of governmental and aid agencies. A study has been implemented over a 4-year period using hydrogeological techniques - e.g. water-table mapping, drilling boreholes, setting up pumping tests, monitoring groundwater levels and rainfall, analysis of water isotopes-together with the geophysical magnetic resonance sounding (MRS) method. Based on new developments in the application of MRS for assessing aquifer specific yield (Vouillamoz et al. 2012a, 2014a), a sizable MRS survey has been conducted for quantifying aquifer storage and recharge. From the unrivalled data set obtained, the groundwater resource of shallow sandstones that are targeted by local drillers has been estimated for the first time in the Oddar Meanchey province.

\section{Area of investigation}

The investigated area $\left(3,375 \mathrm{~km}^{2}\right)$, located in the eastern part of Oddar Meanchey province (Fig. 1), covers the districts of Along Veng and Trapeang Prasat where about 71,000 people were living in 2008, which was about $30 \%$ of the total population of the province (National Institute of Statistics 2009). Ninety per cent of the rainfall occurs from April to October (1, $754 \mathrm{~mm} /$ year on average, see section "Aquifer recharge" and Fig. 9) and the annual mean air temperature is $29^{\circ} \mathrm{C}$.

The area is a plain which gently slopes from the north-east to the south-west and is mainly drained by the Stoeng Sreng River, which discharges to Tonle Sap Lake. Most of the rivers dry up after the rainy season and there is no perennial runoff. To the north, the plain ends at the Dangrek Hills along the border with Thailand. The Dangrek Hills, formed from sandstones dating from Upper Triassic to Lower Cretaceous (Dottin 1972), are the edge of a sandstone escarpment which extends into Thailand. The beds are gently dipping to the north $\left(5-8^{\circ}\right)$ and they comprise conglomerates, fine-tocoarse-grained sandstone and variegated siltstone and mudstone. Tectonic faulting in the sandstones has not been observed (Dottin 1972). In the investigated area, the sandstones have been eroded (they clearly outcrop further south) and then have been covered by alluvium dating from the Pleistocene to the Holocene (known as Old Alluvium). The alluviums which are composed of clay, silt and sand are the most widespread geological unit in the investigated area. They are thin (i.e. few meters thick), thus making outcropping of the upper sandstones possible in different places (Fig. 1). The south of the investigated area is probably an anticline of east-northeast to the west-south-west direction, of the DevonoCarboniferous substratum, which locally outcrops as Phnom (i.e. small isolated hills) in the south-west of the area (Dottin 1972).

\section{Materials and method}

The study was implemented over a 4-year period (2011-2014) and combined several methods including statistical analysis of a database of 211 wells, geophysics and pumping tests at nine experimental sites, 79 measurements of MRSs to complement aquifer properties, estimation of recharge from the monitoring of 12 piezometers (including six coupled with rain gauges), two piezometric campaigns at 36 locations, and water isotopes analyses from 24 wells and rainfall.

\section{Estimation and supplementation of aquifer productivity and storage}

The only available data regarding groundwater in the study area were from the well inventory of the national database (Ministry of Rural Development of Cambodia 2010). Among the 332 records, only wells with coordinates and described basic properties were selected; these were then added to a set of 30 wells (drilled by the CRC/FRC within the framework of this study) out of which the total number of wells used for the study was 211. Based on this data set, basic statistics and spatial patterns of drilling success rate (i.e. ratio of the number of successful wells that have an instantaneous yield higher than $0.5 \mathrm{~m}^{3} / \mathrm{h}$ to the total number of drilled wells), well depth and productivity (i.e. instantaneous yield and specific capacity) were documented. Moreover, 61 drilling reports were available at the CRC/FRC office whose lithologs were used to complement the description of the geological context given by Dottin (1972).

For assessing aquifer transmissivity $(T)$ and specific yield (Sy), nine experimental sites were setup all over the study area. At every experimental site, pumping tests were carried out using a pumping well and one or two observation wells located between 8 and $23 \mathrm{~m}$ away from the pumping well. Pumping durations lasted between 72 and $120 \mathrm{~h}$ and pumping yields ranged between 1.3 and $9.4 \mathrm{~m}^{3} / \mathrm{h}$. Pumping tests were interpreted by Vouillamoz et al. (2012a) using analytical solutions and drawdown log-derivative analysis (Renard et al. 2009) implemented in AQTESOLV/Pro v4.5 software.

To complement the transmissivity $(T)$ obtained at the nine experimental sites, a relationship between the transmissivity 
and the specific capacity $(Q / s)$ was defined (e.g. Razack and Huntley 1991). Using this relationship, transmissivity values were calculated at 108 locations scattered over the investigated area where $Q / s$ was documented in borehole reports.

To complement Sy obtained at the experimental sites, the geophysical MRS method was used. The description of the MRS method and its application to characterize aquifers can be found in numerous publication (e.g. Baroncini-Turricchia et al. 2014; Legchenko 2013; Lubczynski and Roy 2007; Vouillamoz et al. 2007, 2008). The main interest of MRS as compared to other geophysical method is to measure a signal that is generated by groundwater itself, thus making the link between geophysical parameters and hydrogeological properties rather direct. The main parameters derived from MRS interpretation are the depth distribution of water content and decay time $T_{2}{ }^{*}$, i.e. an MRS parameter which is linked to the average size of the pores that contain groundwater (Schirov et al. 1991). Vouillamoz et al. (2012a, b) carried out MRS at the nine experimental sites to compare the MRS decay time [ms] with Sy [-] obtained from pumping tests, and they found:

$$
\begin{aligned}
& \text { if } T_{2}{ }^{*}<130 \mathrm{~ms} \Rightarrow S y \rightarrow 0 \\
& \text { if } T_{2}{ }^{*}>130 \mathrm{~ms} \Rightarrow S y=1.8 \cdot 10^{-4} \cdot T_{2}{ }^{*}-0.02
\end{aligned}
$$

In this study, 79 additional MRS measurements were carried out to calculate $S y$ at 79 locations with Eq. (1). The groundwater storage $\mathrm{GW}_{\text {storage }}[\mathrm{m}]$ was also calculated as (Vouillamoz et al. 2015):

$\mathrm{GW}_{\text {storage }}=S y \cdot \Delta z$

where $S y$ [-] is the specific yield derived from Eq. (1) and $\Delta z$ $[\mathrm{m}]$ is the thickness of the saturated aquifer obtained from MRS interpretation.

The MRS measurements were carried out using the Numis $^{\text {Plus }}$ apparatus from Iris Instruments with a squareshaped loop of 50-100 m length per side, thus giving an investigation depth of 50-70 m below ground level (Bernard 2007). The measurements were interpreted with Samovar V11.43 software (Legchenko et al. 2008).

\section{Estimation of aquifer recharge}

Both the well-known water-table fluctuation method (WTFM) and the stable isotopes analysis have been used for estimating the recharge. To apply the WTFM, 12 dedicated piezometers were drilled and equipped with automatic pressure recorders. The pressure was recorded on an hourly basis and then corrected according to the change in atmospheric pressure recorded at two locations. On a regular basis (i.e. about once a month), a manual measurement of the static water level (SWL) was carried out for comparison with the automatic pressure record, and adjustments where implemented if required. The total recharge $R[\mathrm{~m}]$ was calculated as:

$R=S y \cdot \Delta H$

where $S y[-]$ is the specific yield, and $\Delta H[\mathrm{~m}]$ is the change in water table over the time interval $\Delta t=1$ day. To calculate the total recharge $R$ (sometimes referred as gross recharge), $\Delta H$ is set equal to the sum of the observed water-table rise and the recession (Healy and Cook 2002). The change in groundwater storage (sometimes referred as net recharge) was calculated on a yearly time scale as (Healy and Cook 2002):

$\Delta S^{\mathrm{gw}}=\mathrm{Sy} \cdot\left(H_{\max }-H_{\min }\right) /\left(t_{\max }-t_{\min }\right)$

where $\Delta S^{\mathrm{gw}}$ [m/year] is the annual change in groundwater storage, $H_{\max }[\mathrm{m}]$ is the higher level of the water table that occurs at day $t_{\max }$ and $H_{\min }[\mathrm{m}]$ is the lower level of the water table that occurs at day $t_{\min }$.

Next to six piezometers, an auger rain gauge equipped with a datalogger was also installed to look for the link between recharge and rainfall. The auger rain gauges was checked using an appropriate procedure (i.e. adding a known volume of water at a controlled intensity) and the rain flowing out of the augers was collected into buried containers for crosschecking the recorded volume of rain. Rainfall events and groundwater level were monitored for 4 years at the six locations equipped with a piezometer and rain gauge. At the six other locations only equipped with a piezometer, the groundwater level was monitored for a shorter duration, i.e. 1248 months.

To better understand the process of the recharge, 52 analyses of stable isotopes of oxygen and hydrogen (i.e. ${ }^{18} \mathrm{O}$ and ${ }^{2} \mathrm{H}$ ) were done, including six analyses of rain samples. Groundwater samples were collected in September 2012 and then between April and December 2014 at 24 locations scattered over the investigated area. Rain samples were collected in May, June, August, September and October 2014, that is, between the early and the late rain events of the monsoon. Rainwater was collected in containers that were connected to rain gauges by a pipe. To prevent isotopic fractionation due to evaporation, the pipes reached the bottom of the containers; the containers were properly closed and they were buried to be protected from the sunlight. The collected rainwater was composed of several rain events that occurred within 1-2 months. The samples were sent to a laboratory in Thailand (Bangkok) to carry out the analyses. Two piezometric monitoring campaigns were also carried out by measuring 
the surface-water level (SWL) at 36 locations in November 2012 (after the monsoon) and May 2013 (before the next monsoon).

\section{Results}

\section{Boreholes statistics}

Of the 211 boreholes of the database, there were 37 unsuccessful holes (i.e. instantaneous yield $Q$ i measured after well development is less than $0.5 \mathrm{~m}^{3} / \mathrm{h}$ ), thus giving a success rate of $82 \%$. However, numerous unsuccessful boreholes are most probably not reported and thus are not recorded in the national database; indeed, when only considering the well-controlled database of CRC/FRC ( 69 wells, which are part of the 211), the success rate is $64 \%$. This latter figure is consistent with the anecdotal observations of drillers. Note that the use of geophysics (i.e. resistivity and MRS) for siting boreholes in Oddar Meanchey province has increased the success rate of the CRC/FRC from $64 \%$ (39 wells) to $97 \%$ (30 wells), as previously observed in the neighbouring province of Siem Reap (Vouillamoz et al. 2002). The success rate seems to be higher in the north-east of the area, but the major finding is that positive and negative boreholes can be as close as a few tens of meters, thus indicating a strong spatial heterogeneity of the aquifers.

The median depth of the drilling wells is $31 \mathrm{~m}$, and $80 \%$ of the well depths range between 22 and $49 \mathrm{~m}$ (Fig. 2a). The wells were first drilled using the rotary technique in the unconsolidated alluvium and then using the down-the-hole hammer technique in the consolidated rocks. Eighty per cent of the wells were drilled by rotary drilling down to $1-11 \mathrm{~m}$ below ground surface, thus confirming that the unconsolidated sediment cover is thin and is not the preferred target of drilling, although it can be the target for hand-dug wells. Eighty-three per cent of the targeted consolidated sandstones are described as clayey and/or thin matrix (i.e. claystone and mudstone, Fig. 1). Some boreholes have found schist rock attributed to the Devono-Carboniferous substratum in the south-west of the area where the remaining upper sandstone deposit is thin because it has been deeply eroded. Some boreholes found volcanic rocks (probably Trachytes) attributed to the same geological period as the upper sandstones which outcrop further south-east of the province (Dottin 1972).

The median instantaneous yield $(Q \mathrm{i})$ measured at the end of the well development is $2.3 \mathrm{~m}^{3} / \mathrm{h}$ with $80 \%$ of the values ranging between 1.4 and $4 \mathrm{~m}^{3} / \mathrm{h}$. The specific capacity $(Q / s)$ of the wells is log-normally distributed with a median value of $1.3 \cdot 10^{-4} \mathrm{~m}^{2} / \mathrm{s}$ with $80 \%$ of the values ranging between 3.4 . $10^{-5}$ and $7.4 \cdot 10^{-4} \mathrm{~m}^{2} / \mathrm{s}$ (Fig. 2b). There is no clear link between the $Q / s$ and the well depth (Fig. 2c), and the deepest wells having a low $Q / s$ value, probably reflecting the tendency of drillers to drill deeper when the yield is poor. Most of the wells located in the east and north-east of the surveyed area have a $Q /$ $s$ higher than the median value, while the $Q / s$ values of the wells located at the centre of the area are usually less than the median value (Fig. 3). However, as already observed with the
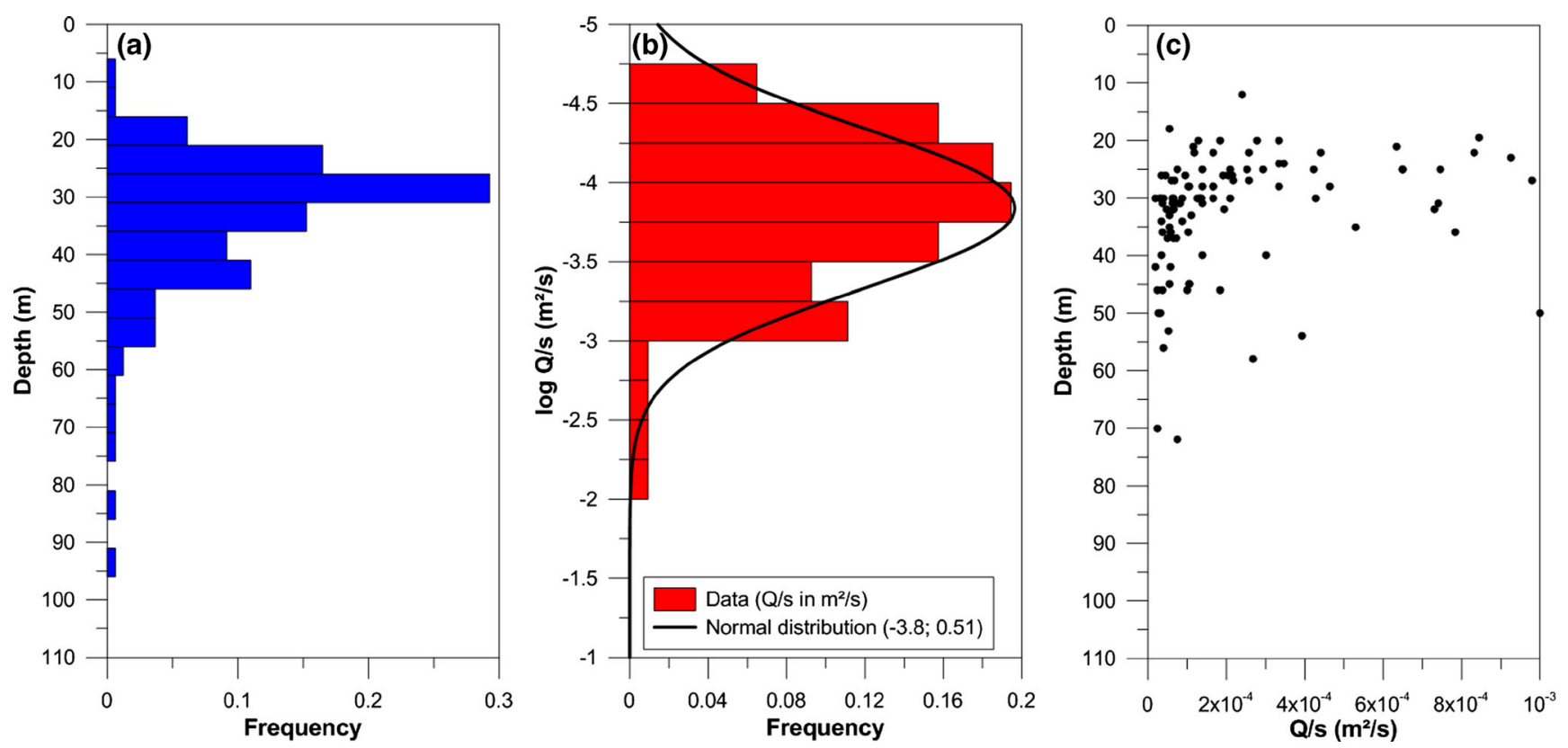

Fig. 2 Boreholes characteristics: a depth frequency (164 wells); b specific capacity frequency (108 wells); c specific capacity vs depth (108 wells) 
Fig. 3 Specific capacity (108 wells)

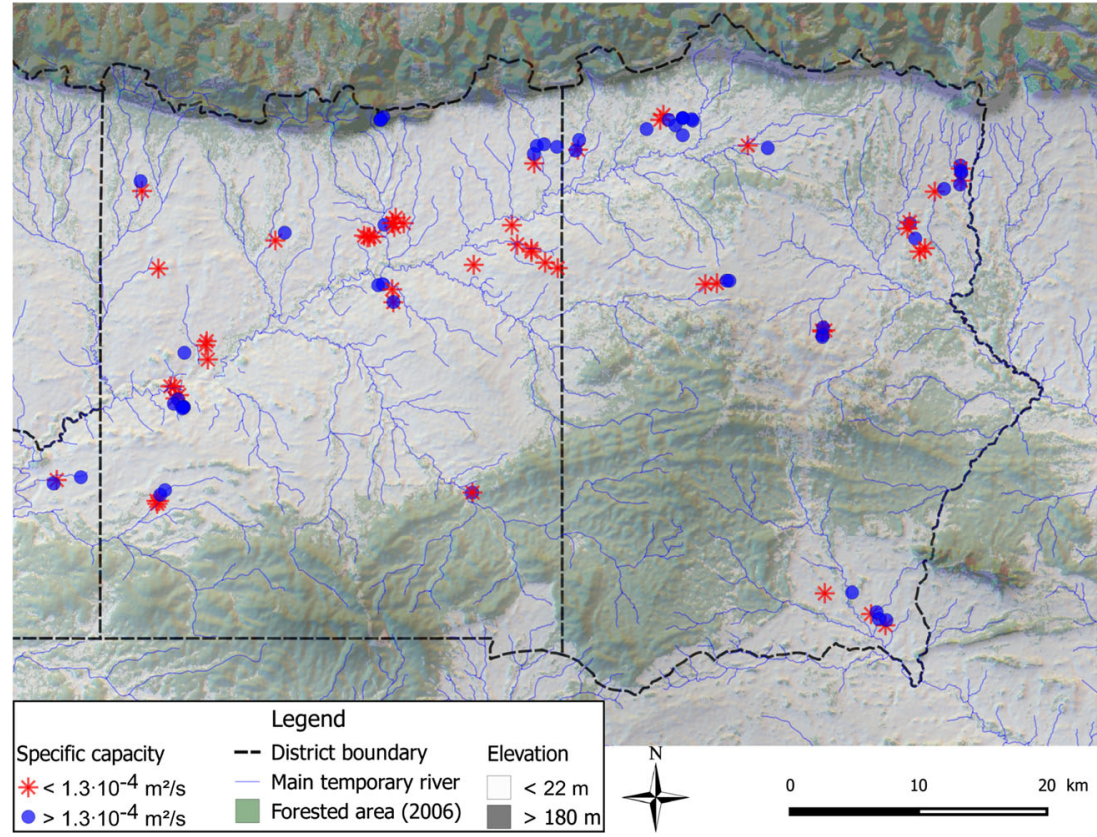

borehole success rate, highly productive wells can be located at only a few tens of meters from poorly productive wells.

\section{Piezometric map}

The piezometric map drawn from the 36 measurements completed at the end of the monsoon in November 2012 indicates that the water table approximately replicates the topography (Fig. 4a). The average depth of the water table below ground level is $4 \mathrm{~m}$. At the end of the dry season (May 2013), the water table was about $2 \mathrm{~m}$ below the water table after the monsoon at any elevation (Fig. 4b), thus indicating that the horizontal component of flow does not change seasonally.

\section{Aquifer transmissivity and storage}

Eighty per cent of the transmissivities $(T)$ obtained from the interpretation of the pumping test at the nine experimental sites range between $1.6 \cdot 10^{-5}$ and $5.1 \cdot 10^{-3} \mathrm{~m}^{2} / \mathrm{s}$ with a median value of $2.9 \cdot 10^{-4} \mathrm{~m}^{2} / \mathrm{s}$. The transmissivity is well linked to the specific capacity calculated at the pumping well (Fig. 5a). As already observed by hydrogeologists, the link is a power function (e.g. Huntley et al. 1992; Razack and Huntley 1991):

$T=2.48 \cdot 10^{8} \cdot(Q / s)^{2.97}$

where $T\left[\mathrm{~m}^{2} / \mathrm{s}\right]$ is the transmissivity calculated using the drawdown in the observation borehole and $Q / s$ is the specific capacity calculated at the pumping well $\left[\mathrm{m}^{2} / \mathrm{s}\right]$. To complement the transmissivity obtained at the nine experimental sites over the investigated area, $T$ was calculated with Eq. (5) using $Q / s$ derived from 108 boreholes of the well database (Fig. 5b). The calculated median transmissivity is $3.4 \cdot 10^{-4} \mathrm{~m}^{2} / \mathrm{s}$ and $80 \%$ of the values range between $1.2 \cdot 10^{-5}$ and $1.1 \cdot 10^{-2} \mathrm{~m}^{2} /$ $\mathrm{s}$ (Table 1). The range of transmissivity calculated from $Q / \mathrm{s}$ values is only slightly larger than the range of transmissivity obtained from the pumping tests at the experimental sites, thus validating the use of Eq. (5) at the 108 locations.

The specific yield has been calculated with Eq. (1) using the 79 MRSs carried out over the investigated area. Two examples of MRS records and interpreted models are presented in Fig. 6, together with the lithology obtained from the boreholes cuttings. O'Tameng was drilled in eluvial sand and O'Russey in sandstone. The geophysical signal, and thus the interpreted models, are strongly different: the MRS water content is higher at O'Tameng as compared to O'Russey (i.e. respectively 9.5 and $1 \%$ ), but the $T_{2}{ }^{*}$ parameter, which is linked to the average size of the pores, is shorter at O'Tameng, thus indicating a lower value of specific yield (Eq. 1). Finally, the groundwater storage calculated with Eq. (2) is higher at O'Russey as compared to O'Tameng because of higher specific yield and thicker saturated layer (i.e. 230 and $90 \mathrm{~mm}$ respectively, Eq. 2).

The range of $S y>0$ calculated with Eq. (1) using the 79 MRSs is between 0.3 and $2 \%$ (Table 1). Twenty-seven of the 79 measurements indicate a specific yield null (i.e. $T_{2}^{*}<130 \mathrm{~ms}$, 
Fig. 4 a Piezometric map at the end of the monsoon ( 36 measurements); $\mathbf{b}$ comparison of piezometry before and after the monsoon

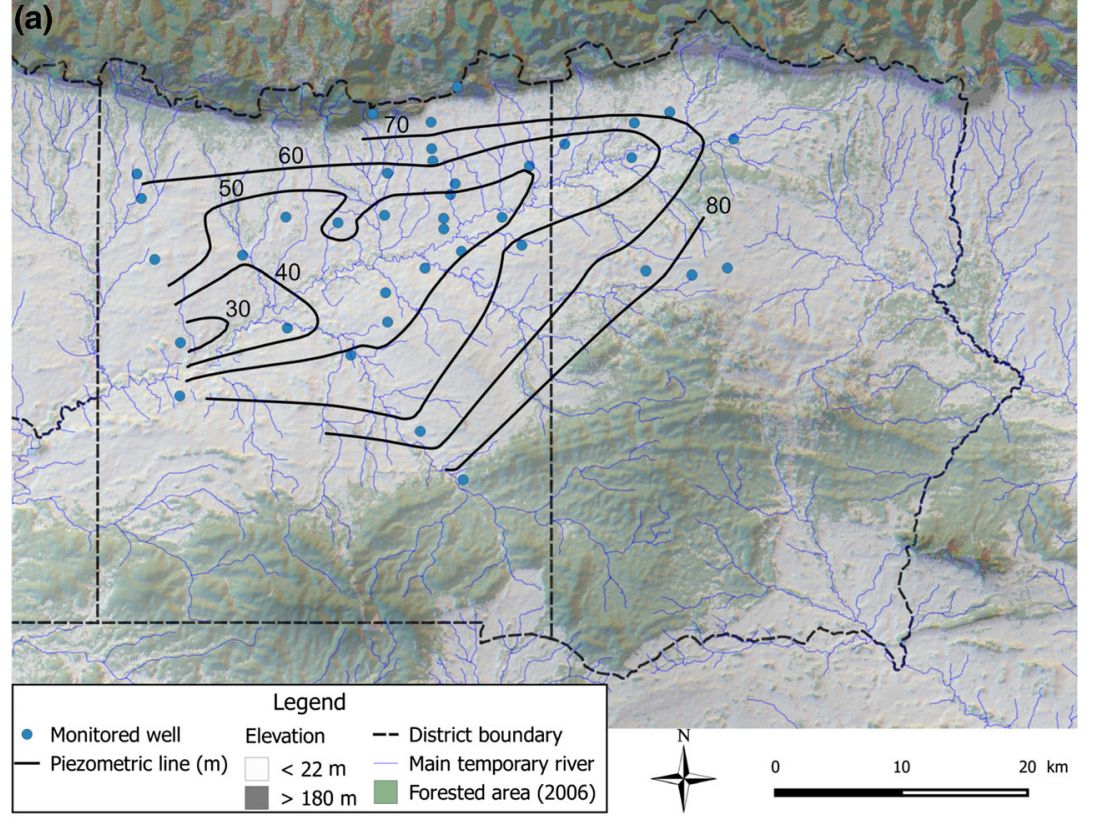

(b)

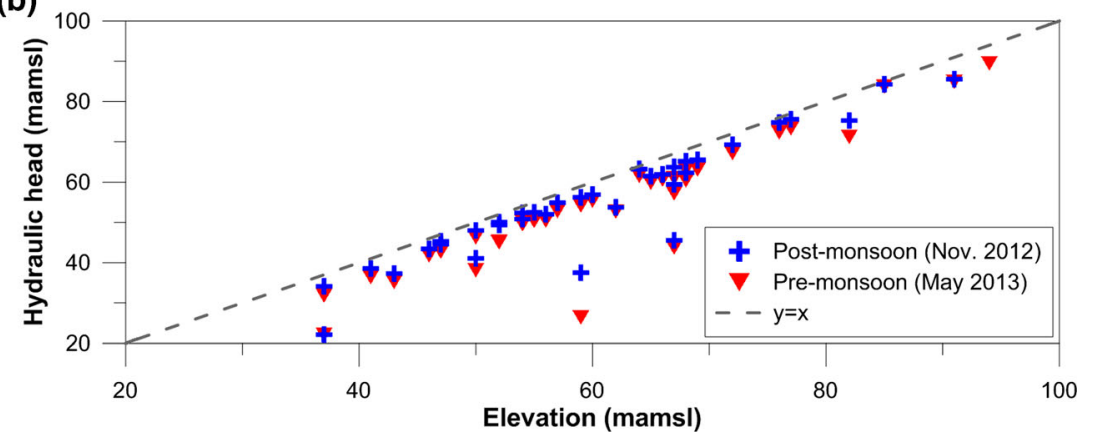

Eq. 1), which means that $34 \%$ of the surveyed locations do not have significant groundwater reserve; this value is in accordance with the drilling statistics which indicate that $36 \%$ of the drilled holes are negative (see section "Boreholes statistics"). The median groundwater storage calculated with Eq. (2) is $173 \mathrm{~mm}$, and $80 \%$ of the values range between 62 and $400 \mathrm{~mm}$. There is no clear spatial pattern for the storage (Fig. 7).

\section{Aquifer recharge}

The recharge calculated at the 12 sites where the water-table fluctuation was recorded (Fig. 8) ranges between 10 and $70 \mathrm{~mm}$ with a median of $28 \mathrm{~mm}$ (Table 1). The rainfall values recorded at the six monitoring locations from 2011 to 2015 are variable: the median annual rainfall is $1,871 \mathrm{~mm}$ (Table 1) but the variation is large both in space and in time. The maximum annual rainfall recorded at O'Angre in $2013(2,437 \mathrm{~mm})$ is about twice the minimum rainfall recorded at Padeak Chrum in $2012(1,219 \mathrm{~mm})$. This large rainfall heterogeneity gives the opportunity to assess the relationship between the recharge and the rainfall. When considering the six sites where the rainfall was recorded together with the fluctuation of the water table (Fig. 9), the ratio of the annual total recharge to the annual rainfall is stable for each site: the higher the rainfall, the higher the recharge. Eighty per cent of the annual total recharge values range between 0.5 and $4.3 \%$ of the annual rainfall with a median ratio of $1.5 \%$. Obviously, the annual change in groundwater storage (i.e. the net recharge, Eq. 4) follows the same pattern as the total recharge: it is closely linked to the annual rainfall (Fig. 10a). If one considers the link to be linear, aquifers will not be recharged if annual rainfall falls below $750-1,000 \mathrm{~mm}$. Currently, the storage is in equilibrium with the mean rainfall of about $1,700 \mathrm{~mm}$ : when annual rainfall is below the mean value, the annual storage balance (i.e. the difference in storage between the 1st of January and the 31 st of December the same year) is negative; 
Fig. 5 a Transmissivity versus specific capacity at the 9 pumping test sites; $\mathbf{b}$ transmissivity calculated at 108 location using Eq. (5)
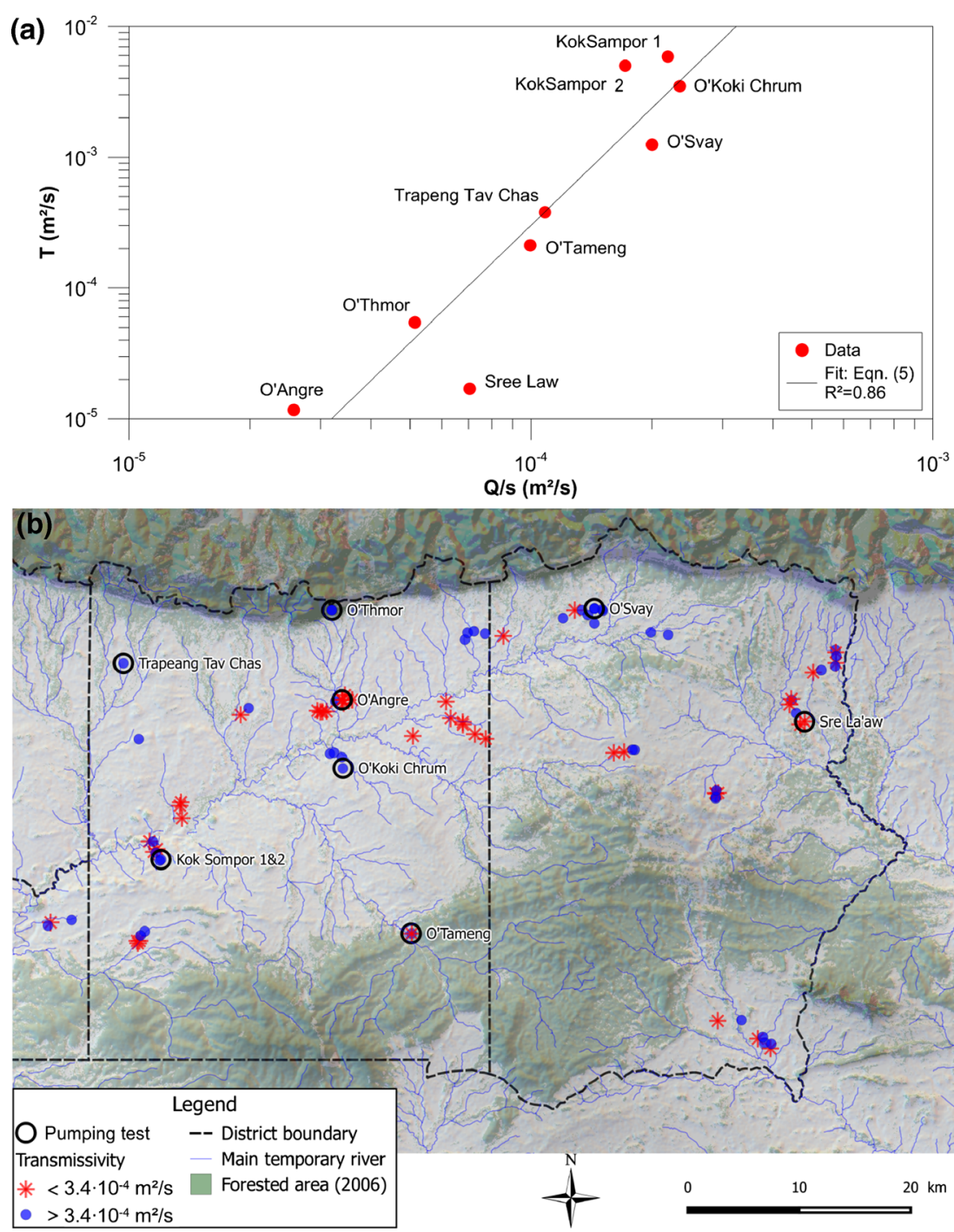

on the other hand, the annual storage balance is positive when the annual rainfall is higher than about 1,700 $\mathrm{mm}$ (Fig. 10b).

The analyses of stable isotopes are plotted in Fig. 11 together with the global meteoric water line (GMWL). The stable isotopes ratio of rainfall fits the GMWL well. The range of values of the rainfall is similar to the range observed in central Cambodia by Kabeya et al. (2007) and in Bangkok (IAEA nucleus database). The 46 groundwater data collected
Table 1 Aquifer properties, recharge and rainfall

\begin{tabular}{|c|c|c|c|c|c|}
\hline Aquifer property & Data set & $\begin{array}{l}\text { No. of } \\
\text { values }\end{array}$ & $\begin{array}{l}\text { Decile } \\
\text { No. } 1\end{array}$ & Median & $\begin{array}{l}\text { Decile } \\
\text { No. } 9\end{array}$ \\
\hline Thickness [m] & Borehole & 164 & 22 & 31 & 49 \\
\hline \multirow[t]{2}{*}{ Transmissivity $\left[\mathrm{m}^{2} / \mathrm{s}\right]$} & Pumping test & 9 & $1.6 \cdot 10^{-5}$ & $2.9 \cdot 10^{-4}$ & $5.1 \cdot 10^{-3}$ \\
\hline & Well database & 108 & $1.2 \cdot 10^{-5}$ & $3.4 \cdot 10^{-4}$ & $1.1 \cdot 10^{-2}$ \\
\hline \multirow[t]{2}{*}{ Specific yield [\%] } & Pumping test & 5 & 0.2 & 0.9 & 2.4 \\
\hline & MRS & 52 & 0.3 & 0.9 & 2 \\
\hline Storage $[\mathrm{mm}]$ & MRS & 52 & 62 & 173 & 400 \\
\hline Annual recharge $[\mathrm{mm}]$ & Well-year $^{\mathrm{a}}$ & 31 & 10 & 28 & 70 \\
\hline Annual rainfall $[\mathrm{mm}]$ & Rain-year $^{\mathrm{a}}$ & 24 & 1,698 & 1,871 & 2,228 \\
\hline
\end{tabular}

${ }^{a}$ Well-year and rain-year are the number of wells and rain-gauges which have been monitored multiplied by the number of monitoring years 
(a) MRS data and fitted model

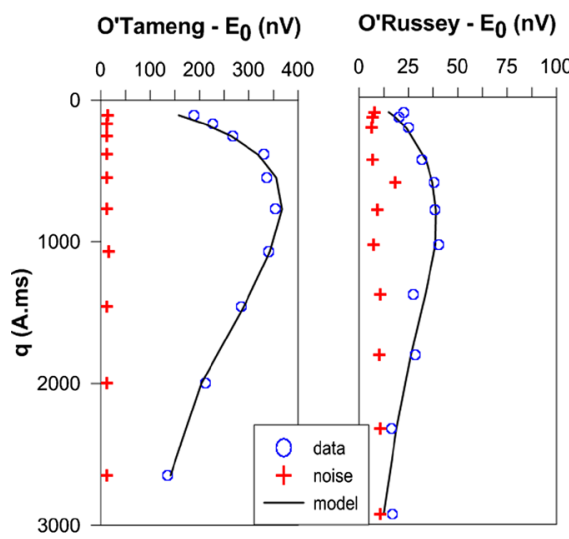

(b) Borehole and MRS model

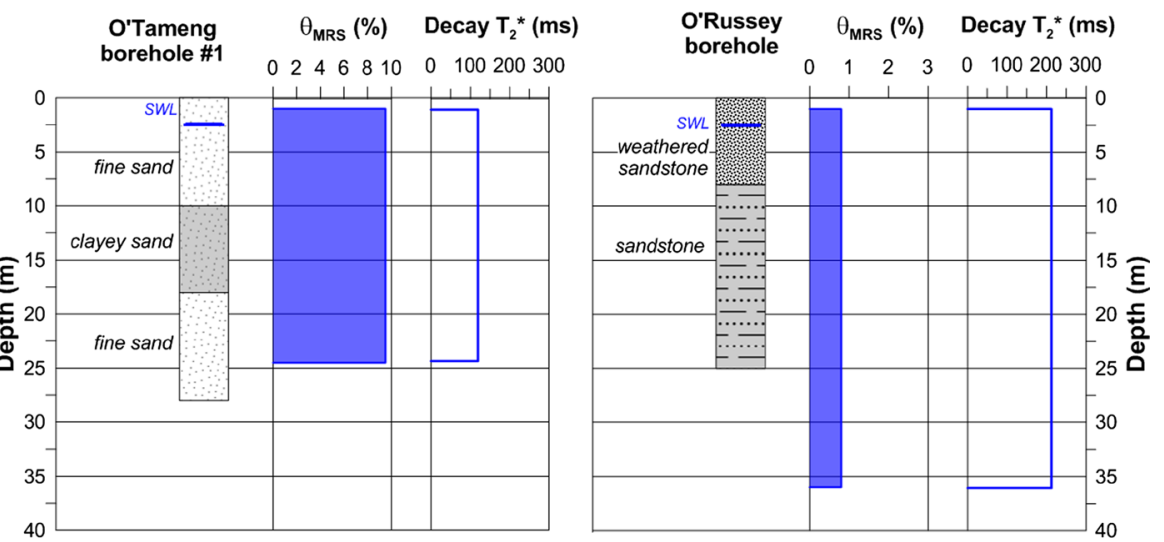

Fig. 6 Example of magnetic resonance sounding $(M R S)$ : a MRS field measurement; $\mathbf{b}$ MRS model and lithology. $q$ is the pulse parameter of the sounding, $E_{0}$ is the initial amplitude of the signal, $\theta_{M R S}$ is the water content and $T_{2} *$ is the decay parameter (Legchenko 2013)

at 24 different sites are aligned on the GMWL, thus indicating diffuse recharge, i.e. no evaporation of rainfall before water reaches the aquifer (Kabeya et al. 2007).

\section{Discussion}

\section{Aquifer properties and recharge}

The synthesis of the findings regarding the aquifer properties and recharge is plotted in Fig. 12. The transmissivity ranges from very low to medium and is comparable to the values of unconsolidated alluvium of the neighbouring province of Siem Reap (Vouillamoz et al. 2002). The storage ranges from 62 to $400 \mathrm{~mm}$ (median of $173 \mathrm{~mm}$ ). To the authors' knowledge, estimations of groundwater storage in Cambodia have never been published. As compared to the storage estimated in other countries for unconsolidated aquifers (e.g. Vouillamoz et al. 2012b) as well as in weathered hard rock aquifers (e.g. Vouillamoz et al. 2015), the storage of the sandstone aquifer is low, thus confirming the clayey nature of the sandstone. The borehole depth ranges from 22 to $49 \mathrm{~m}$ (median of $31 \mathrm{~m}$ ). The thickness of the aquifer is assumed to be almost equal to the borehole depth because the drillers usually stop drilling when the drilling duration is too long (i.e. $15-20 \mathrm{~min} / \mathrm{m}$ when using the down-the-hole hammer technique), reflecting the change in the lithology into a more consolidated rock (i.e. the substratum). Note that some drillings are probably
Fig. 7 Groundwater storage (52 locations)

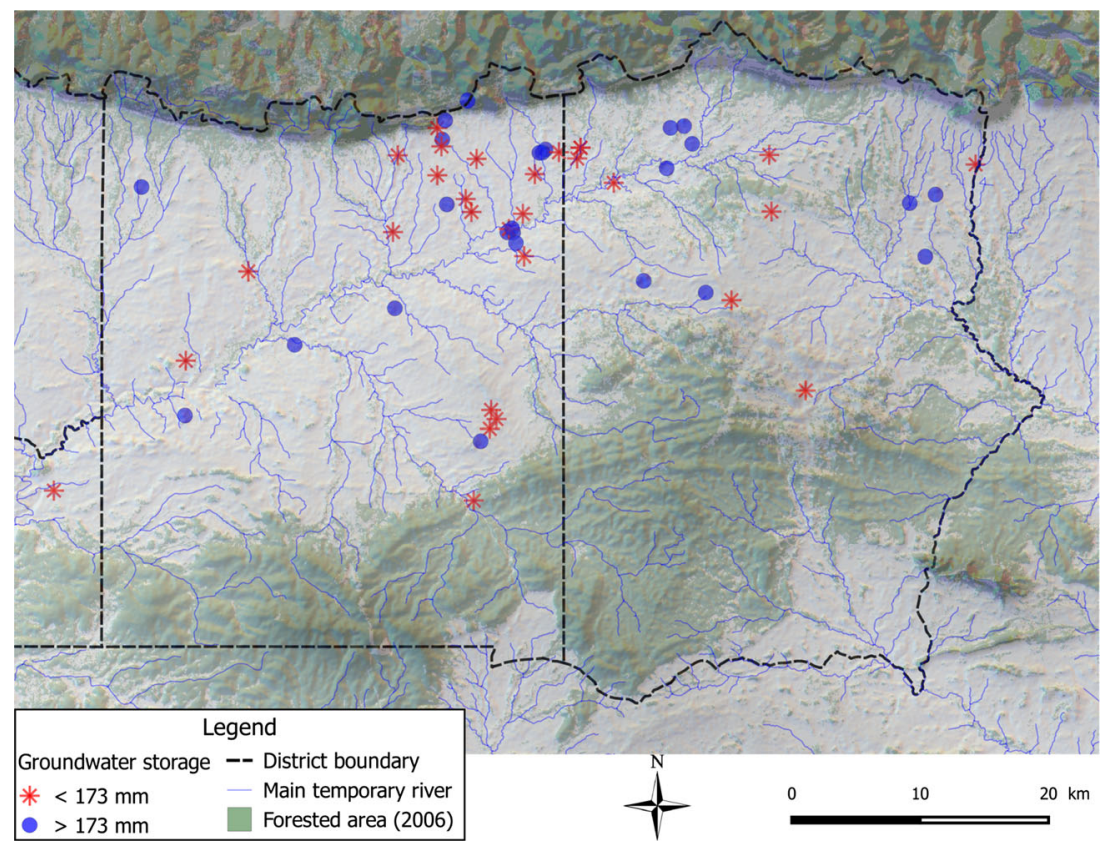


Fig. 8 Groundwater recharge (12 locations)

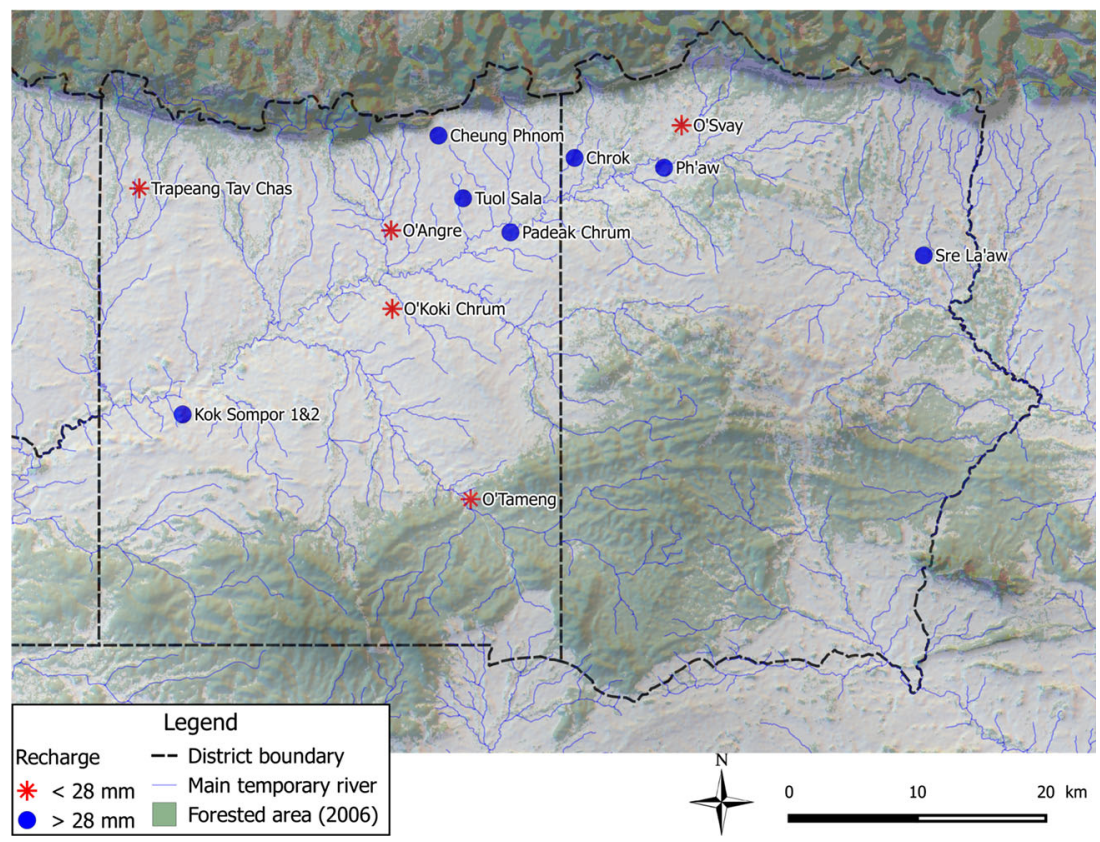

stopped when the yield is high enough, which can bias the thickness estimate.

The median recharge that occurred during the 4 years of the study is $28 \mathrm{~mm}(10-70 \mathrm{~mm})$, which represents only a small percentage of the rainfall (from 0.5 to $4.3 \%$ ). To the authors' knowledge, no previous study has estimated the recharge in the Upper Triassic to Lower Cretaceous sandstones in Cambodia. Estimations of recharge have been carried out in unconsolidated younger sediments using several approaches of groundwater modelling (IDE 2009), water balance (JICA and MRD 2002), interaction of small streams and shallow groundwater (Araki et al. 2008), or modelling of floods of the Mekong River (Kazama et al. 2007). The recharge estimated for this study is based on numerous field observations (i.e. a total of 31 annual data obtained from the monitoring of 12 sites) which have been interpreted with the water-table fluctuation method (WTFM). WTFM assumes that the groundwater moves away from the recharge location at a rate that is slower than the rate at which recharge water arrives from ground surface (Healy and Cook 2002). Assuming this is the case in this study, the application of the method is valid. The comparison of piezometry before and after the rainy season indicates that the horizontal component of the groundwater flow does not change seasonally, thus suggesting a diffuse recharge, i.e. a discharge that is distributed all over the area as a direct response to rainfall events. The isotopic analyses also confirm that rainwater infiltrates directly and rapidly (i.e. no prior evaporation).

Although the data set produced in this study by field characterization of the aquifer is unique in Cambodia (i.e. 108 values of transmissivity, 79 values of storage and 31 values of recharge over an area of $3,375 \mathrm{~km}^{2}$ ), there is no clear proof of any spatial pattern in the distribution of the properties. The aquifer in the east and north-east of the investigated area generally seems more productive, but transmissivity and storage can be highly different at the scale of a few tens of meters. The main explanation for the variation of the properties of the aquifer is probably the variation of clay content of the sandstones.

A few boreholes that reached the substratum (schist in Fig. 12b) below the sandstone are clearly more productive than boreholes drilled in the common sandstone. Unfortunately, this observation could not be confirmed with new boreholes since the two attempts to drill deep enough into the Devono-Carboniferous substratum were unsuccessful: the drilling rig was either not powerful enough or the hole too unstable to reach the targeted depth at Kok Sampor village. Note that the cost of deep drilling is several orders higher than the shallow drillings, making aid agencies focus on the latter.

\section{Groundwater resource}

The first question asked by the humanitarian and development actors to the researcher concerns the use of groundwater to supply people with drinking water. The national census of 2008 recorded the population of the investigated area at 71 , 651 (National Institute of Statistics 2009). The average annual growth rate between 2008 and 2013 in Oddar Meanchey province was $4.39 \%$ (National Institute of Statistics 2009, 2013) and the national average rate is estimated to be $1.38 \%$ from 2013 to 2030 (UNICEF 2015), thus giving a total population in the investigated area of about 112,000 people in 2030 . 
Today, the daily water consumption is not known exactly but it might increase as people move out of poverty. Assuming that the daily consumption will increase to $100 \mathrm{~L}$ per capita per day, and assuming that the entire supply will come from groundwater abstraction, the required volume will be 11 , $200 \mathrm{~m}^{3} /$ day or $1.2 \mathrm{~mm} /$ year of equivalent water thickness. As compared to the current groundwater recharge $(R \approx$ $28 \mathrm{~mm} /$ year), the abstraction for domestic supply is definitively low. Moreover, the groundwater storage $\left(\mathrm{GW}_{\text {storage }}=173 \mathrm{~mm}\right)$ can clearly buffer any change in the recharge, thus increasing the resilience of the population to climate or anthropogenic changes.

The second question asked by the practitioners concerns the role groundwater can play to support food production, and mainly rice. As presented in the "Introduction" section, the objective is to supply supplementary irrigation to the
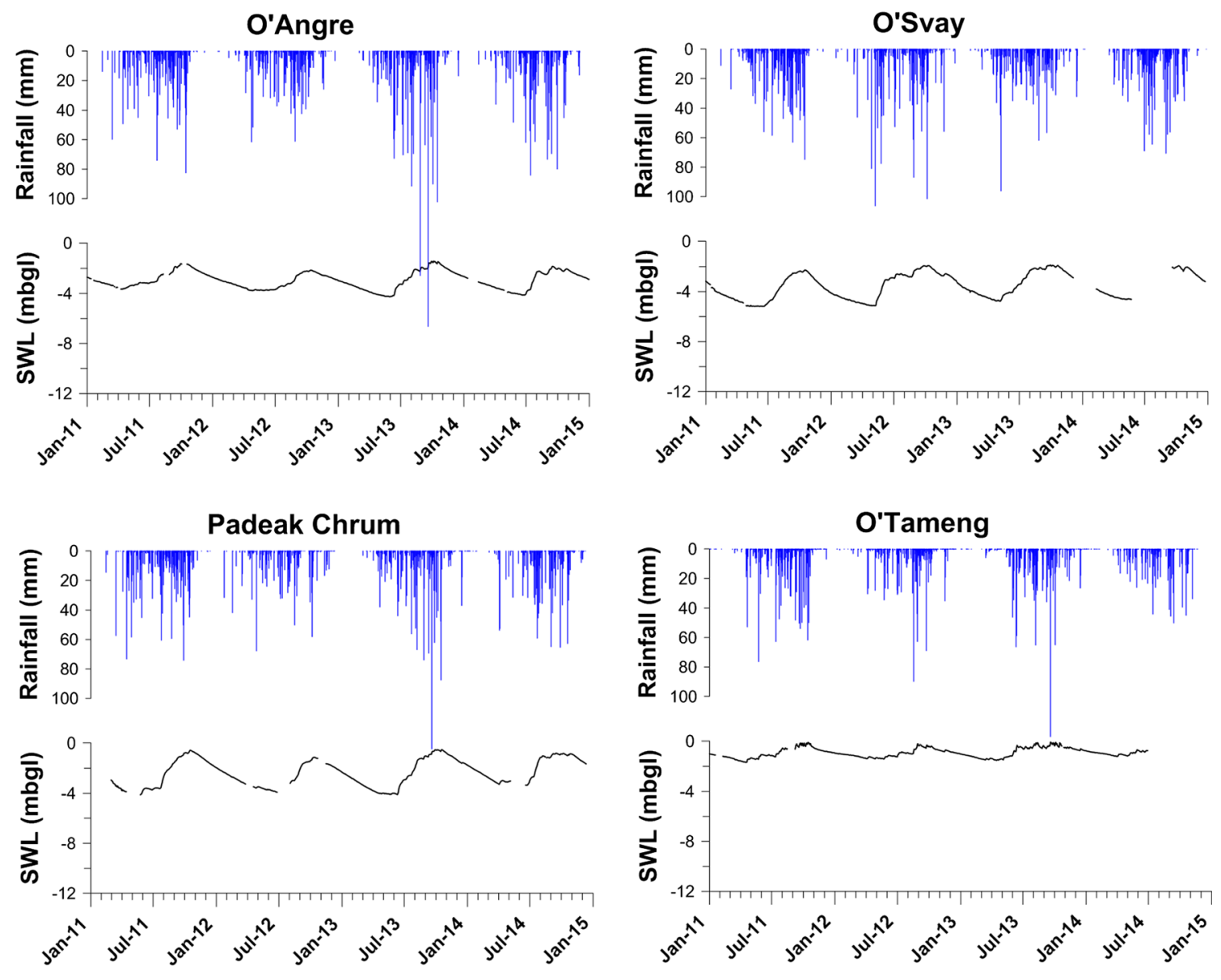

Trapeang Tav Chas
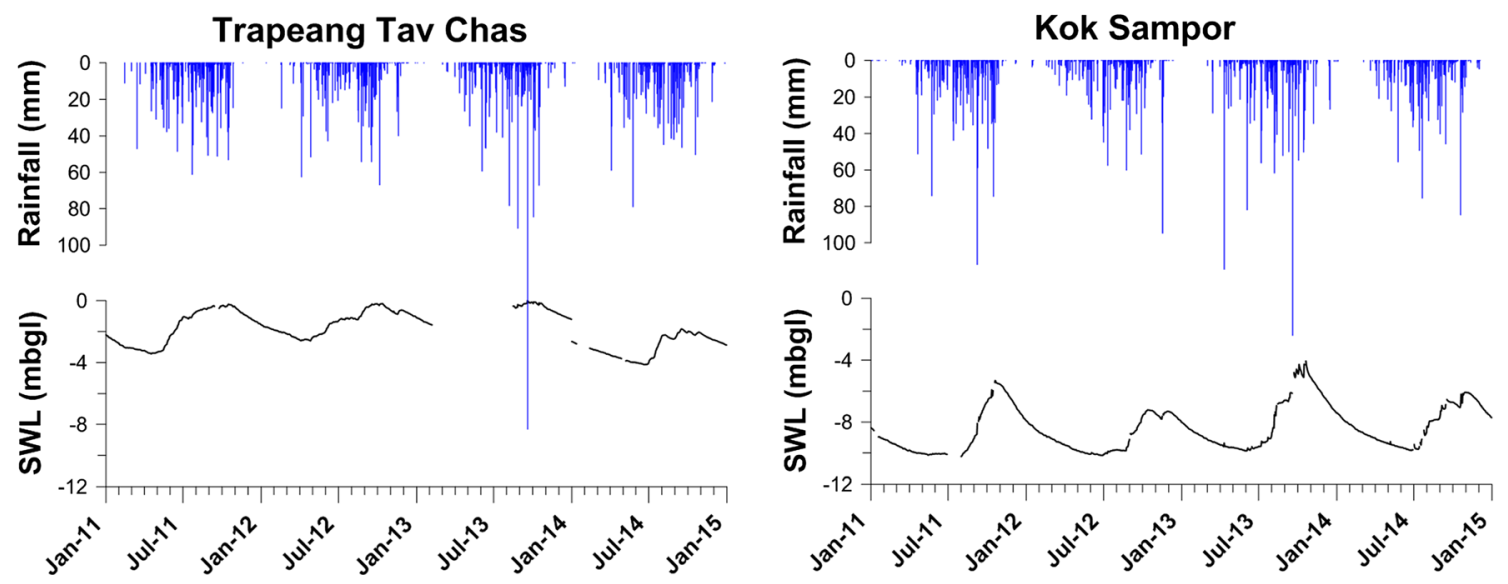

Fig. 9 Static water level $(S W L)$ and daily rainfall ( $\mathrm{mbgl}$ is meters below ground level) 
Fig. 10 Relationship between rainfall and storage: a change in storage (net recharge) versus rainfall; $\mathbf{b}$ storage balance between Jan. and Dec. versus rainfall

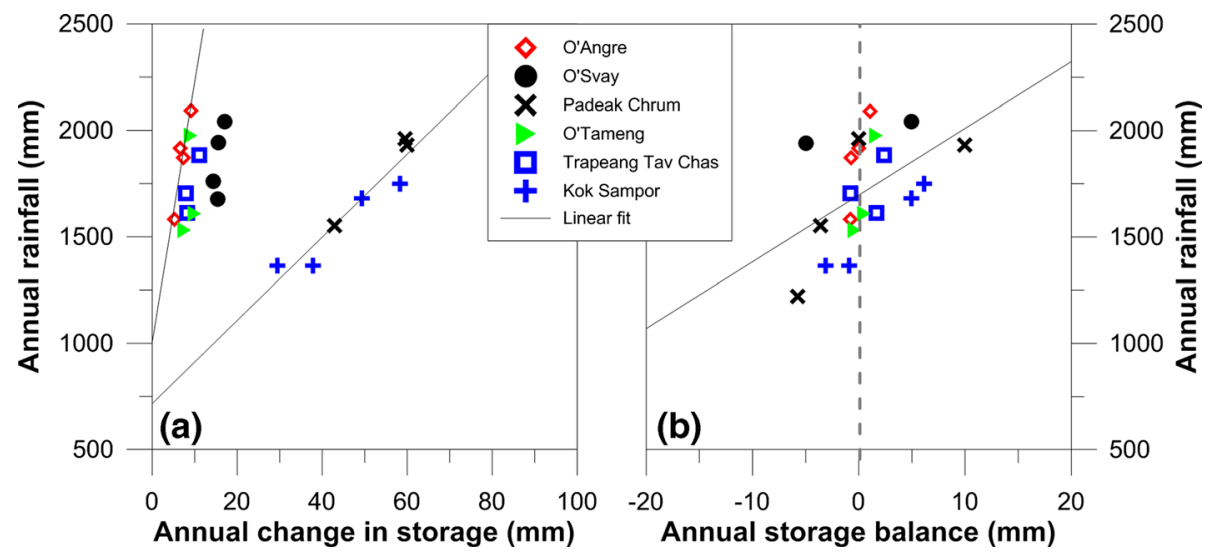

paddy fields when the onset of the rainy season is late. Since data on the frequency of late onset of the monsoon is not available (i.e. it requires a long duration of rainfall monitoring that does not locally exist), the estimate of the duration of the so-called drought is based on a survey carried out on 200 people in the investigated area. Interviews revealed that the need for supplementary irrigation can last 2 months, from May to June. The rice-crop water requirement in the study area can be estimated using the reference evapotranspiration (Allen et al. 1998) calculated from weather data recorded at
Fig. 11 Stable isotopes analyses: a groundwater sampling locations (24 sites); b stable isotopic composition of rainfall ( 6 samples) and groundwater (46 samples)
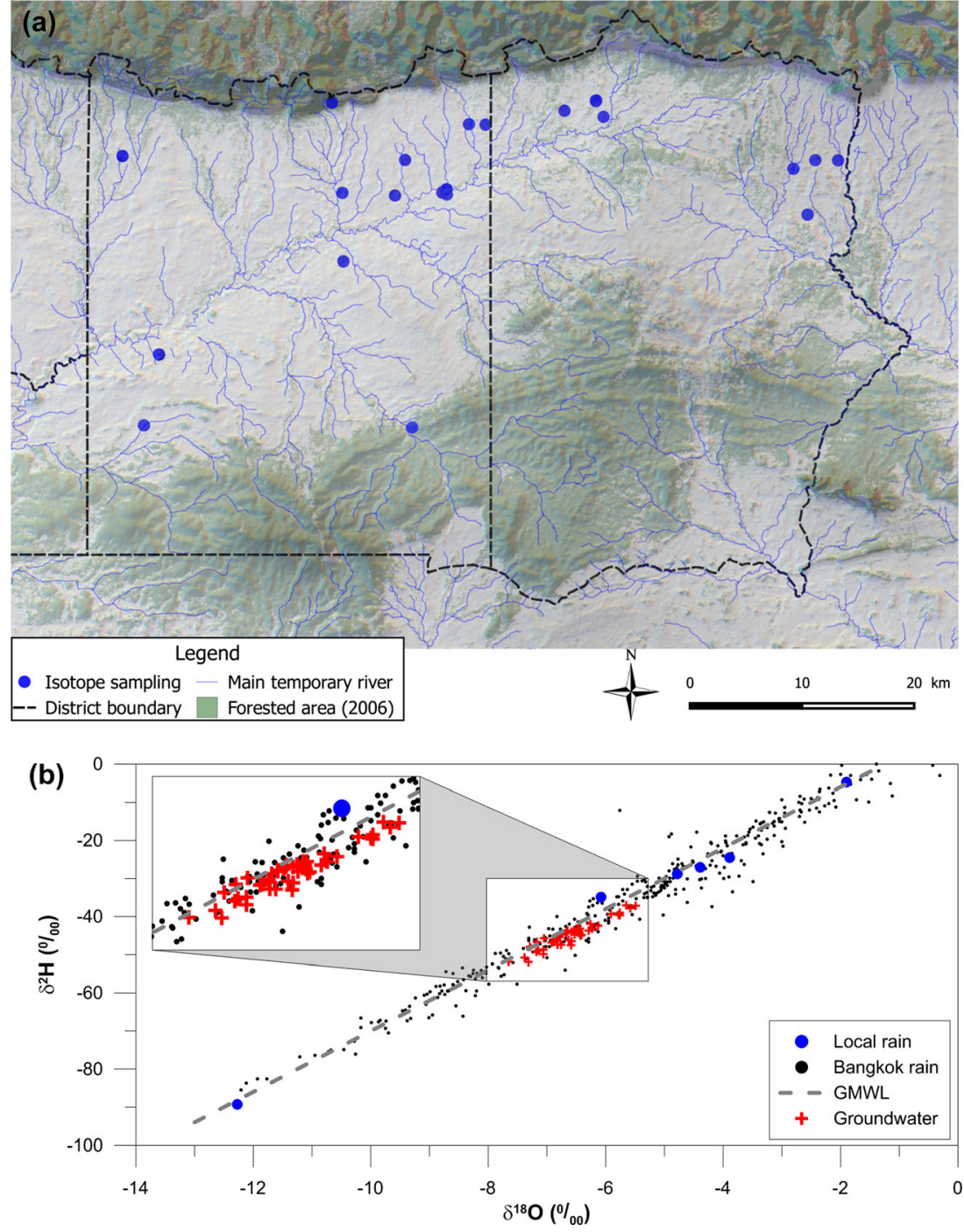


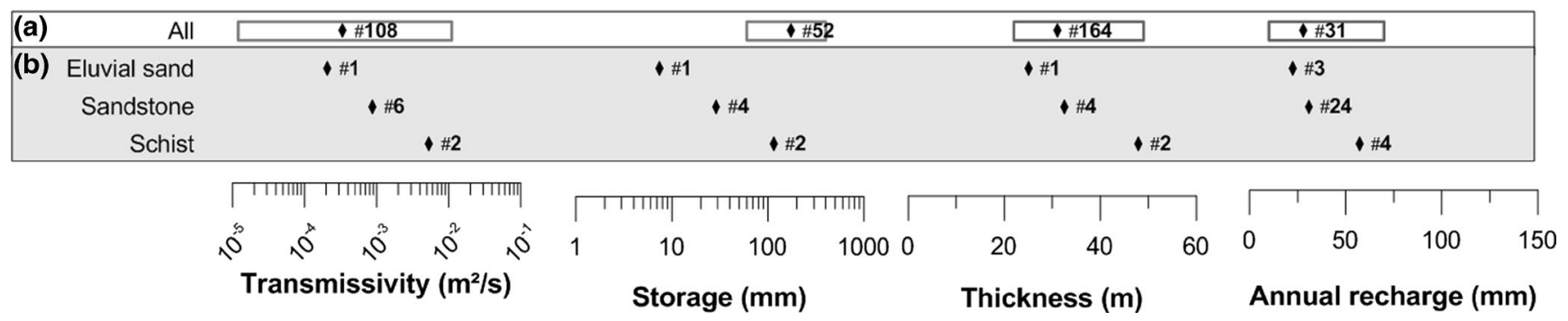

Fig. 12 Synthesis of aquifer characterization: a All data sets (the diamond is the median, the range is given by the deciles); b data set according to the lithology (the diamond is the median). Numbers are the number of data used for the calculation

Along Veng from 2011 to 2014. The reference evapotranspiration was $3.3 \mathrm{~mm} /$ day on average in May and June with a narrow range of variation (i.e. standard deviation of 0.38 ). Adding distribution losses, the water requirement is estimated to be $6 \mathrm{~mm} /$ day, which is in the range of the estimates in other provinces of Cambodia (from 5 to $10 \mathrm{~mm} /$ day, e.g. Chem et al. 2011; IDE 2009). Thus, $60 \mathrm{~m}^{3} /$ day of water is required for supplying a paddy field of a surface area of 1 ha (hectare), which is the common surface area required for a family (Mund 2011). To estimate if the sandstone aquifer can produce $60 \mathrm{~m}^{3}$ daily over 2 months, a simple model based on the well-flow analytical solution is set up (Kruseman and de Ridder 2000). The use of a confined (Theis) or unconfined (e.g. Neuman with $S=S y / 100$ ) analytical solution has a limited impact on the simulated maximum drawdown (i.e. difference of $3 \%$ ). A first model is set up using the median properties of the sandstone aquifer. The result indicates that the maximum drawdown after 60 days of pumping ( $10 \mathrm{~h}$ of pumping per day) is about $6 \mathrm{~m}$ (Fig. 13), which is probably the maximum acceptable value, since it is about $23 \%$ of the median aquifer thickness. Thus, only half of the sandstones surveyed in the study can supply a family rice plot of $1 \mathrm{ha}$. A second model is then set up using the properties of the schist rocks which exhibited the highest transmissivity and specific yield values encountered in the framework of the study (Fig. 12). The result indicates that $300 \mathrm{~m}^{3}$ can be pumped daily (maximum drawdown of about $7 \%$ of aquifer thickness), which can supply about 5 ha of paddy field or five family plots (Fig. 13). These results obtained with the use of the Theis analytical solution are optimal results since they do not consider that aquifers can be heterogeneous (e.g. presence of a no flow boundary within the radius of influence of the pumping, which is more than $1 \mathrm{~km}$ for the modelled pumping), and the results do also not consider the head losses created by the well, which can drastically increase the calculated drawdown (Kruseman and de Ridder 2000). Finally, the pumping simulations indicate that the sandstone aquifer can generally not be used for large-scale supplementary irrigation for rice crops; only specific locations would produce enough water for supplementary irrigation at the family scale (i.e. $1 \mathrm{ha}$ ), and a site-specific study is necessary to define the amount of water that can be produced. Because the water requirement is far less for vegetables than for rice crops (i.e. smaller surface area and a water requirement of a shorter duration), groundwater can be used to water gardens.

Concerning groundwater quality, the investigated area is usually classified in the "low" to "very low" risk of arsenic pollution (e.g. Berg et al. 2007); however, a systematic control of the arsenic content is recommended when groundwater is used for drinking, cooking or irrigation (e.g. Lado et al. 2008) in areas where no or only few data have been collected; thus, arsenic concentration was checked by the FRC/CRC in 2010 before the beginning of the study. All the samples collected in 138 wells scattered in the investigated area indicated an arsenic concentration less than $2 \mu \mathrm{g} / \mathrm{L}$ (the WHO guideline for drinking water is $10 \mu \mathrm{g} / \mathrm{L}$ ).

\section{Replicability of the study}

This study was carried out in the framework of a collaborative project between two parties, i.e. aid agencies (Cambodian and French Red Cross, CRC/FRC) and a French research institute (Institut de Recherche pour le Développement, IRD). The interest in such a collaboration is the complementarity of the

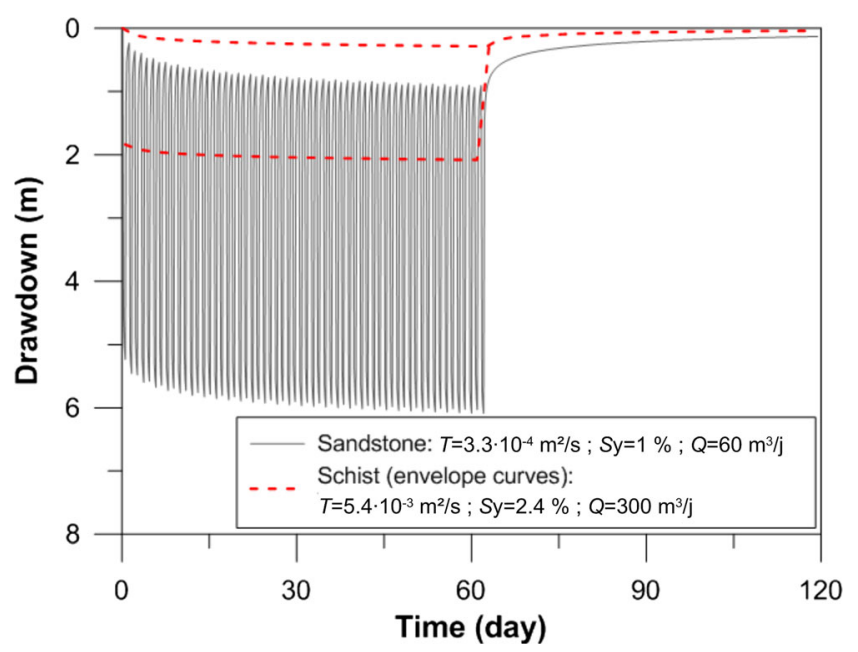

Fig. 13 Modelled drawdown for $10 \mathrm{~h}$ of daily pumping for 2 months 
skills. On the one hand, aid agencies have direct access to the human communities and have effective logistics to implement activities in the field, while, on the other hand, scientists can support aid agencies to address development challenges through specific inputs. Lessons learned from this 4-year study indicate that the compulsory conditions to be met to obtain useful results for both parties are (1) scientific activities and expected results clearly defined and integrated in the proposal of the development project, (2) dedicated staff and budget allocation to implement the scientific field work, and (3) a sufficiently long period of time for assessing the hydrological cycle, i.e. 4-5 years. Fulfilling these conditions may lead to a successful replication of such a study in other regions.

\section{Conclusion}

This work is the first ever study carried out on the groundwater resource in Oddar Meanchey province to support governmental and aid agencies in the implementation of drinkingwater supply and food security projects. The study was implemented over a 4-year period from 2011 to 2014. Hydrogeological techniques were used together with the geophysical MRS method, resulting in an estimation of aquifer productivity, storage and recharge. It was found that the sandstone aquifer is generally clayey, thus exhibiting a low-tomedium transmissivity and a median storage of $173 \mathrm{~mm}$. The recharge has been quantified to range between 10 and $70 \mathrm{~mm}$ or $0.5-4.3 \%$ of the annual rainfall. Based on this unique data set, the capacity of the sandstone aquifer to supply $100 \mathrm{~L}$ of drinking water daily to the expected population in 2030 has been checked and it was found that the sandstone aquifer can easily supply drinking water to the Oddar Meanchey people. However, the shallow sandstone aquifer can generally not supply enough water for the large-scale supplementary irrigation of rice. Because the aquifer is heterogeneous, it can locally exhibit more advantageous properties that can be sufficient for irrigating small plots for a few families for about 2 months. Detailed studies will have to be carried out at the local scale for quantifying the potential for such irrigation.

Deeper aquifers have not been studied in this work, even if some results indicated that groundwater resources can be higher in the fractured schist of the Devono-Carbonifereous substratum as compared to the surveyed Upper TriassicLower Cretaceous clayey sandstone. The development of a new project focussing on the deeper groundwater resource can hopefully confirm this assumption and then propose new options for using groundwater for irrigation.

Finally, groundwater is a component of the water cycle and a more comprehensive assessment of the water resource can be achieved by an integrated water resource survey. This study is a first step in the quantification of the water resource of
Oddar Meanchey province, and it aims at suggesting that appropriate quantitative studies must be promoted to support strategies to address current needs and to adapt to future demands.

Acknowledgements The authors would like to thank the reviewers as well as the associate editor for their helpful comments and thorough review of the manuscript. This work has been carried out in the framework of the Institut de Recherche pour le Développement and the French Red Cross collaborative project 39842A1-1R012-RHYD, with financial support of the European Union (grant DIPECHO SEA ECHO/DIP/BUD/ 2010/01017 and grant DCI-FOOD/2011/278-175). We thank S. Sokheng, $P$. Sophoeun and $O$. Bruyère for their efficient assistance in field work. We also thank H. Thyberghien, A. Petibon, L. Anstett and A. Chappate for making this project possible.

Open Access This article is distributed under the terms of the Creative Commons Attribution 4.0 International License (http:// creativecommons.org/licenses/by/4.0/), which permits unrestricted use, distribution, and reproduction in any medium, provided you give appropriate credit to the original author(s) and the source, provide a link to the Creative Commons license, and indicate if changes were made.

\section{References}

Allen R, Peirera LS, Raes D, Smith M, (1998) Crop evapotranspiration. FAO irrigation and drainage paper no. 56, FAO, Rome. http://www. fao.org/docrep/x0490e/x0490e00.htm. Accessed 22 March 2015

Araki M, Shimizu A, Kabeya N, Nobuhiro T, Ito E, Ohnuki Y, Tamai K, Toriyama J, Tith B, Pol S, Lim S, Khorn S (2008) Seasonal fluctuation of groundwater in an evergreen forest, central Cambodia: experiments and two-dimensional numerical analysis. Paddy Water Environ 6:37-46. doi:10.1007/s10333-008-0114-1

Baroncini-Turricchia G, Francés AP, Lubczynski MW, MartínezFernández J, Roy J (2014) Integrating MRS data with hydrologic model: Carrizal Catchment (Spain). Near Surf Geophys 12:255269. doi:10.3997/1873-0604.2014003

Berg M, Stengel C, Trang PTK, Hung Viet P, Sampson ML, Leng M, Samreth S, Fredericks D (2007) Magnitude of arsenic pollution in the Mekong and Red River deltas: Cambodia and Vietnam. Sci Total Environ 372:413-425. doi:10.1016/j.scitotenv.2006.09.010

Bernard J (2007) Instruments and field work to measure a magnetic resonance sounding. Bol Geol Min 118(3):459-472

Chem P, Hirsch P, Someth P (2011) Hydrological analysis in support of irrigation management. No. CRDI working paper no. 59, CRDI, Phnom Penh, Cambodia. www.cdri.org.kh/webdata/download/wp/ wp59e.pdf. Accessed 22 March 2015

Dottin O (1972) Carte géologique de reconnaissance: Siem Reap [Geological map: Siem Reap]. BRGM, Orléans, France

Healy RW, Cook PG (2002) Using groundwater levels to estimate recharge. Hydrogeol J 10:91-109. doi:10.1007/s10040-001-0178-0

Huntley D, Nommensen R, Steffey D (1992) The use of specific capacity to assess transmissivity in fractured-rock aquifers. Ground Water 30: 396-402. doi:10.1111/j.1745-6584.1992.tb02008.x

IDE (2009) Strategic study of groundwater resources in Prey Veng and Svay Rieng (Phase 2). IDE, Phnom Penh, Cambodia. http://idecambodia.org/index.php?option=com_php\&Itemid=37\&lang=en. Accessed 21 March 2015

Johnston R, Roberts M, Try T, de Silva S (2013) Groundwater for irrigation in Cambodia. http://www.iwmi.cgiar.org/Publications/issue briefs/cambodia/issue brief 03-groundwater_for_irrigation in cambodia.pdf. Accessē 20 March 2015 
Kabeya N, Shimizu A, Chann S, Tsuboyama Y, Nobuhiro T, Keth N, Tamai K (2007) Stable isotope studies of rainfall and stream water in forest watersheds in Kampong Thom, Cambodia. In: Forest environments in the Mekong River Basin. Springer, Japan, pp 125134

Kazama S, Hagiwara T, Ranjan P, Sawamoto M (2007) Evaluation of groundwater resources in wide inundation areas of the Mekong River basin. J Hydrol 340:233-243. doi:10.1016/j.jhydrol.2007. 04.017

Kruseman GP, de Ridder NA (2000) Analysis and evaluation of pumping test data. ILRI, Wageningen, The Netherlands

Lado LR, Polya D, Winkel L, Berg M, Hegan A (2008) Modelling arsenic hazard in Cambodia: a geostatistical approach using ancillary data. In: Arsenic in groundwaters of South-East Asia: with emphasis on Cambodia and Vietnam. Appl Geochem 23:3010-3018. doi:10. 1016/j.apgeochem.2008.06.028

Landon M (2011) Preliminary compilation and review of current information on groundwater monitoring and resources in the Lower Mekong River Basin. USGS, Reston, VA

Legchenko A (2013) Magnetic resonance imaging for groundwater. Wiley-ISTE, Chichester, UK, p 235

Legchenko A, Ezerski A, Girard JF, Baltassat JM, Boucher M, Camerlynk C, Al-Zoubi A (2008) Interpretation of magnetic resonance soundings in rocks with high electrical conductivity. J Appl Geophys 66:118-127. doi:10.1016/j.jappgeo.2008.04.002

Lubczynski M, Roy J (2007) Use of MRS for hydrogeological parameterization and modelling. Bol Geol Min 118(3):509-530

Ministry of Rural Development of Cambodia (2010) The online well database of the Kingdom of Cambodia. Ministry of Rural Development of Cambodia, Bangkok. http://www. cambodiawellmap.com/. Accessed 19 March 2015

MRD, JICA (2002) The study on groundwater development in southern Cambodia: final report. JICA, Tokyo. http://libopac.jica.go.jp/ images/report/P0000053695.html. Accessed 21 March 2015

Mund JP (2011) The agricultural sector in Cambodia: trends, processes and disparities. Pac News 35:10-14

National Institute of Statistics (2009) Cambodia: general population census of Cambodia 2008 no. DDI-KHM-NIS-GPCC-2008-v1.0. Ministry of Planning, Phnom Penh. http://nada.nis.gov.kh/index. $\mathrm{php} / \mathrm{catalog} / 1$. Accessed 19 March 2015

National Institute of Statistics (2013) Cambodia inter-censal population survey 2013. National Institute of Statistics, Phnom Penh http:// countryoffice. unfpa.org/cambodia/?publications $=8711$. Accessed 19 March 2015

Nesbitt H (1997) Rice production in Cambodia. International Rice Research Institute, Los Baños, Philippines. http://books.irri.org/ getpdf.htm?book=9712201007. Accessed 20 March 2015

Rasmussen WC, Bradford GM (1977) Ground-water resources of Cambodia. US Geol Surv Water Suppl Pap 1608-P. http://pubs.er. usgs.gov/publication/wsp1608P. Accessed 20 March 2015

Razack M, Huntley D (1991) Assessing transmissivity from specific capacity in a large and heterogeneous alluvial aquifer. Ground Water 29:856-861. doi:10.1111/j.1745-6584.1991.tb00572.x
Renard P, Glenz D, Mejias M (2009) Understanding diagnostic plots for well-test interpretation. Hydrogeol J 17(3):589-600. doi:10.1007/ s10040-008-0392-0

Schirov M, Legchenko A, Creer G (1991) New direct non-invasive ground water detection technology for Australia. Explor Geophys 22:333-338. doi:10.1071/EG991333

UNICEF (2015) The world's children 2015 country statistical table. UNICEF, New York. http://www.unicef.org/infobycountry/ cambodia statistics.html. Accessed 22 March 2015

Vouillamoz JM, Descloitres M, Bernard J, Fourcassié P, Romagny L (2002) Application of integrated magnetic resonance sounding and resistivity methods for borehole implementation: a case study in Cambodia. J Appl Geophys 50:67-81. doi:10.1016/S09269851(02)00130-1

Vouillamoz JM, Chatenoux B, Mathieu F, Baltassat JM, Legchenko A (2007) Efficiency of joint use of MRS and VES to characterize coastal aquifer in Myanmar. J Appl Geophys 61:142-154. doi:10. 1016/j.jappgeo.2006.06.003

Vouillamoz JM, Favreau G, Massuel S, Boucher M, Nazoumou Y, Legchenko A (2008) Contribution of magnetic resonance sounding to aquifer characterization and recharge estimate in semiarid Niger. $\mathrm{J}$ Appl Geophys 64:99-108. doi:10.1016/j.jappgeo.2007.12.006

Vouillamoz JM, Sokheng S, Bruyere O, Caron D, Arnout L (2012a) Towards a better estimate of storage properties of aquifer with magnetic resonance sounding. J Hydrol 458-459:51-58. doi:10.1016/j. jhydrol.2012.06.044

Vouillamoz JM, Hoareau J, Grammare M, Caron D, Nandagiri L, Legchenko A (2012b) Quantifying aquifer properties and freshwater resource in coastal barriers: a hydrogeophysical approach applied at Sasihithlu (Karnataka state, India). Hydrol Earth Syst Sci 16:43874400. doi:10.5194/hess-16-4387-2012

Vouillamoz JM, Lawson FMA, Yalo N, Descloitres M (2014a) The use of magnetic resonance sounding for quantifying specific yield and transmissivity in hard rock aquifers: the example of Benin. J Appl Geophys 107:16-24. doi:10.1016/j.jappgeo.2014.05.012

Vouillamoz JM, Sophoeun P, Bruyere O, Arnout L (2014b) Estimating storage properties of aquifer with magnetic resonance sounding: a field verification in northern Cambodia of the gravitational water apparent cutoff time concept. Surf Geophys 12:211-216. doi:10. 3997/1873-0604.2013038

Vouillamoz JM, Lawson FMA, Yalo N, Descloitres M (2015) Groundwater in hard rocks of Benin: regional storage and buffer capacity in the face of change. J Hydrol 520:379-386. doi:10. 1016/j.jhydrol.2014.11.024

WFP (2008) Kingdom of Cambodia: comprehensive food security and vulnerability analysis (CFSVA). WFP, Washington, DC. https:// www.wfp.org/content/cambodia-comprehensive-food-security-andvulnerability-analysis-2008. Accessed 22 March 2015

WFP (2014) Hunger map. WFP, Washington, DC. http://www.wfp.org/ content/hunger-map-2014. Accessed 22 March 2015

WHO, UNICEF (2014) Progress on drinking water and sanitation. WHO, Geneva. http://www.who.int/water_sanitation_health/publications/ 2014/jmp-report/en/. Accessed 22 March 2015 